distinct from professional, educationists. Nevertheless, there was no protest at the suggestion that, to make way for the necessary instruction in human physiology, either some subject at present in the school curriculum would have to be dropped or a compromise effected by using human physiology as an introduction to, and a vehicle for, the teaching of general biology. It was pointed out that it is a sound pedagogic principle to proceed from the known, or at least the familiar, to the unknown. Study of the human body and of its functions is an admirable introduction to the study of other forms of life and of biological principles in general. Moreover, human physiology gives great scope for practical work with the minimum of apparatus; in short, it is good science, good biology and admirably adapted to school instruction.

Although the day is long past when all mention of human structure and of human function was taboo, yet some fear was expressed during the discussion that teaching of human physiology might lead to unhealthy self-consciousness and introspection on the part of the pupils. The general opinion seemed to be, however, that such a danger is more likely to arise in the course of unofficial health talks conducted by enthusiastic but unskilled instructors than in routine school teaching. Indeed, Prof. Winifred Cullis, from her wide experience, believes that school instruction in human physiology, so far from inducing morbid preoccupation with the functions of the body, would rather tend to ventilate and bring into the unemotional atmosphere of the schoolroom, and thus into proper perspective, many matters which, even to-day, the modern child is shy of discussing with its elders.

The meeting was a very large one for a purely sectional discussion, and the fact that the practising physiologists were in an extremely small minority is an indication of the widespread interest the subject aroused. From every point of view it was unfortunate that a joint discussion with Section L (Educational Science) could not be arranged, for the time has clearly arrived when the place of physiology or human biology in school science courses must be given serious attention.

\title{
Registration and Privilege
}

$T^{1}$ HE extent to which the principles of 'free trade' are inbred in the people of Great Britain is well illustrated by the statutory provisions governing the registration of medical practitioners and pharmacists. For both professions the State establishes standards of education and examination, with a statutory register of those who reach them. To permit the public to differentiate between the qualified and the unqualified practitioner, the use of titles implying registration is prohibited and the signing of death certificates, the sale of poisons, and other minor matters are controlled. But in both medicine and pharmacy the practice of the calling by unregistered men has few statutory limitations.

By way of contrast, the lawyer is well protected. It is a statutory offence for a layman to practise as a solicitor, and in the High Court His Majesty's judges will neither see nor hear the advocate who is not a barrister. Accountants and architects have certain titles reserved to them, but few other statutory privileges. The high-water mark of protection for a calling is probably that given to dentists, the Dentists Act of 1921 making it an offence for the unregistered to "practise dentistry".

Many attempts have been made in recent years to persuade Parliament to regulate the practitioners of a calling by means of a statutory register and to provide statutory privileges for the registered. The destruction of the Osteopaths Bill exemplifies the fate of such attempts. It is in the totalitarian States that there will be found the modern examples of restrictive legislation for the control and benefit of individual callings and their protection from competition. Whether the price to be paid compensates for the advantages, even to the sheltered practitioner himself, is a question the answer to which depends upon the temperament of the individual. The majority of the people of Great Britain are not temperamentally inclined to a régime of professional corporations, even for personal benefits, and that spirit is reflected in the attitude of Parliament towards Bills proposing to accord privileges to closed professions.

Nevertheless, there is a price to be paid for freedom. In the medical and pharmaceutical fields the price is the exploitation of the public by the 
quack. Probably at no time in history has the British public provided so rich a field for the pseudo-scientific medicine-man with his tale of vitamins and hormones, rings, belts and exercises, massages and diets. The Times publishes its National Health Number, with the dominant note of healthy exercise outdoors, while from every hoarding, bus and tram an attempt is make to mesmerize the public into mass drugging.

A year ago, when the House of Commons was invited to discuss this question on the second reading of the Medicines and Surgical Appliances (Advertisement) Bill, the House was counted out. It is small wonder that with public opinion so docile, the proprietary medicine industry was able to claim before the Select Committee on Medicine Stamp Duties in December last that the capital in the industry is $£ 100,000,000$, and that it spends between $£ 12,000,000$ and $£ 15,000,000$ annually in advertising its wares.

\section{Air Raid Precautions}

\section{Air Defence and the Civil Population}

By Dr. H. Montgomery Hyde and G. R. Falkiner Nuttall. Pp. xvi $+239+8$ plates. (London: The Cresset Press, Ltd., 1937.) $12 s .6 d$. net.

$\mathrm{T}$ HIS book has been written for the benefit of the 'man in the street'. It contains a moderate statement of the various risks to which the ordinary citizen may be subjected in an aerial bombardment, and explains the most effective methods of providing protection against themcollective, individual and structural.

The authors are generally in agreement with the recommendations made by the Air Raid Precautions Department of the Home Office, but they submit certain criticisms, the chief of which is the ineffectiveness of its propaganda, as public interest in the subject has not been aroused, nor has readiness on the part of the public to co-operate in defensive measures been achieved to the extent which both the seriousness of the international situation and the progress of military preparations throughout Europe plainly demand. They consider that, in the circumstances, instruction in passive defence should be as integral a part of the life of the nation as vaccination and the registration of vital statistics.

In striking contrast with this apparent apathy, the developments that have taken place in all Continental countries-including Holland and the Seandinavian group which were neutral in the Great War-are briefly summarized. In Germany, Italy and Russia a standard knowledge of antigas precautions is obligatory, and the whole civilian community is compelled to co-operate with the authorities in experiments of different kinds. 'Black-outs' are of common occurrence in all the chief cities, and the most realistic conditions are created, including the intentional bursting of water and gas mains and the daubing with red paint of the 'casualties' before they are removed in the ambulances, in order to reproduce the situation that may have to be dealt with : everybody must take cover on the air raid warn. ing being given, and even foreign tourists are punished if they disobey any of the orders. Public shelters are being built and municipal buildings strengthened, while in all important business premises and factories the provision of protection for the employees is compulsory. In Italy, instruction in passive defence measures is given from a series of gramophone records which are sold at specially reduced prices; while in Russia, General Eideman, the head of the Air Defence Department, was among the generals who were recently shot in Moscow, the official explanation given being that his organization was 'on the down grade'!

In Czechoslovakia a law has recently been enacted compelling all housing contractors to provide bomb-proof shelters in the cellars for the protection of their tenants ; and in France, where the experience gained in the construction of the Maginot line has been of particular value, a Bill has been passed empowering the Government to evacuate the civilian population where necessary, and to build bomb- and gas-proof shelters : in the Seine Department alone, $£ 1 \frac{1}{2}$ millions were voted two years ago to finance air raid precautions.

While all these measures are accepted by our neighbours with enthusiastic co-operation, our own lack of interest is all the more remarkable as we are exceptionally vulnerable to attack, and the outstanding characteristic of future air raids is that they may come suddenly and unexpectedly and may well precede any formal declaration of war. (When a practice 'black-out' was suggested in Brighton a few days ago an alderman was reported to have protested against frightening the visitors, while a councillor described the proposals as "this air raid nonsense".) 